\title{
REVIEW
}

\section{Internet resources for neurologists}

\section{R Al-Shahi, P A G Sandercock}

J Neurol Neurosurg Psychiatry 2003;74:699-703

This fourth and final review in the JNNP internet series summarises the essential internet resources for adult and paediatric clinical neurology, neuroradiology, and neurophysiology. This article is freely available on the JNNP website (www.jnnp.com), where-within seconds - the complete list of recommended websites can be easily downloaded and incorporated into your web browser as a Bookmark/Favorite file. The further progress of clinical neurology on the world wide web will be monitored in JNNP Neuronline fillers and JNNP Neurology in Practice supplements.

See end of article for authors' affiliations ...............................

Correspondence to: Dr Rustam Al-Shahi, Department of Clinical Neurosciences, Western General Hospital, Crewe Road, Edinburgh EH4 2XU; rustam.al-shahi@ed.ac.uk

Received

10 February 2003

Accepted

11 February 2003
T he internet has become inescapable and increasingly essential in the everyday practice of neurology, largely because of the unparalleled medical resources on the world wide web (www). The ebb and flow of internet content calls for an update of older reviews of neurology and neuroscience resources. ${ }^{12}$

Rather than attempt a comprehensive summary, which is precluded by the proliferation of the internet, ${ }^{3}$ we have distilled internet content down to a manageable list of high quality portals for easy reference (table 1). Uniform resource locators (URLs) are provided in the text if they are not mentioned in table 1 .

This review concludes the JNNP internet series, which has already covered concepts and websites for medicine in general, ${ }^{4}$ neurosurgery/ neuropathology, and psychiatry/neuropsychiatry. ${ }^{6}$ Our recommendations are based on continual surveillance of the internet, as well as a Medline search from 1966 to 1 August 2001 using the exploded medical subject heading (MeSH) terms, "computer communication networks" and "internet", combined with the MeSH terms, "neurology, neurosciences, neurophysiology, diagnostic imaging".

\section{NEUROLOGY RESOURCES}

Within half a second, the Google search engine (www.google.com) retrieves over 1.5 million websites relating to the search term "neurology" from its computer generated index of www content. But however fast and sensitive search engines are, they are best searched with more specific criteria. ${ }^{47}$ For the neurologist in a hurry, a search engine will often provide something of relevance, even if not of the best quality.

Portals (also known as directories) are more reliable gateways to smaller selections of neurology resources because they are repositories of websites chosen or edited by humans for their quality. Google's directory yields a mere 1850 websites using the same search criterion, and the websites are ranked by their perceived order of relevance.

\section{Neurology portals}

Neurologists and their patients are likely to find that portals specifically dedicated to neurology have a higher yield of pertinent websites than general directories. Neurology portals are distinguished from each other by various attributes including the comprehensiveness of their selection of websites, any bias in their compilation (in language, country of origin, funding, or disease category), the sophistication of software for searching the directory, and their presentation.

Recognising that readers are likely to use at most a handful of portals to direct their further browsing, we have been rather selective. Although the dot.com world is now relatively impoverished, forcing medical website developers to take recourse to advertising (especially from the pharmaceutical industry), we have tried to avoid recommending sponsored sites because they are unsightly and may be biased in their content. Despite the global nature of the internet, reviews of www resources are inevitably biased towards the authors' country/continent of origin, ${ }^{2}$ and we suspect that ours is no exception.

\section{Evidence based neurology portals}

The Trip database is perhaps the most user friendly evidence based resource for neurologists. It is dedicated to bringing together all the evidence based healthcare resources available on the internet, and has a dedicated neurology "clinical area" which issues monthly updates that can be received by email. The Trip database includes coverage of the Cochrane Library, which has review groups dedicated to dementia and cognitive impairment, epilepsy, movement disorders, multiple sclerosis, neuromuscular disease, and stroke. Although the Cochrane Library operates on a subscription basis, free access is provided to low income countries, and many countries have arranged national provisions (www.update-software.com/cochrane/provisions. htm); for example, in England the full text of the library can be accessed through the National Electronic Library for Health (www.nelh.nhs.uk). The Cochrane neurological network (www. cochraneneuronet.org) functions as a link between neurologists and the Cochrane collaboration.

Guidelines for the practice of clinical neurology are not as yet united on one website, presumably because they tend to vary by region. The American Academy of Neurology (AAN) practice guidelines, which are kept updated, are freely available as pdf files on the AAN website. Other 
Table 1 Useful web sites

\begin{tabular}{|c|c|c|}
\hline Site name & URL & Site description \\
\hline \multicolumn{3}{|l|}{ Neurology portals } \\
\hline Trip database & www.tripdatabase.com & $\begin{array}{l}\text { An attempt to bring together all the evidence based health care resources } \\
\text { on the internet, with a dedicated neurology section and email updates }\end{array}$ \\
\hline Cochrane Library & www.update-software.com/cochrane & A synthesis of reliable evidence about the effects of health care \\
\hline $\begin{array}{l}\text { American Academy of Neurology } \\
\text { practice guidelines }\end{array}$ & $\begin{array}{l}\text { www.aan.com/professionals/ } \\
\text { practice/guidelines.cfm }\end{array}$ & North American evidence based aids to clinical decision making \\
\hline Neurosciences on the Internet & www.neuroguide.com & A comprehensive directory of internet neuroscience resources \\
\hline $\begin{array}{l}\text { Online textbooks } \\
\text { eMedicine Neurology } \\
\text { Neuromuscular Diseases Textbook } \\
\text { MedLink Neurology }\end{array}$ & $\begin{array}{l}\text { www.emedicine.com/neuro } \\
\text { www.neuro.wustl.edu/neuromuscular } \\
\text { www.medlink.com }\end{array}$ & $\begin{array}{l}\text { Free multiauthored textbook, covering the whole of medicine } \\
\text { Free multiauthored textbook dedicated to neuromuscular diseases } \\
\text { Subscription only neurology textbook }\end{array}$ \\
\hline \multicolumn{3}{|l|}{ Patient information } \\
\hline $\begin{array}{l}\text { National Institute of Neurologic } \\
\text { Disorders and Stroke }\end{array}$ & www.ninds.nih.gov & USA based funding and information resource \\
\hline $\begin{array}{l}\text { National Organisation for Rare } \\
\text { Disorders }\end{array}$ & www.rarediseases.org & $\begin{array}{l}\text { USA federation of voluntary health organisations dedicated to rare } \\
\text { disorders }\end{array}$ \\
\hline Neurological Alliance & www.neurologicalalliance.org.uk & UK alliance of charities dedicated to neurological diseases \\
\hline Brain and Spine Foundation & www.brainandspine.org.uk & $\begin{array}{l}\text { Foundation to develop research, education and information about } \\
\text { neurological disorders }\end{array}$ \\
\hline \multicolumn{3}{|l|}{ News and discussion } \\
\hline \multicolumn{3}{|l|}{ Neurologists } \\
\hline NeurologyLinx & www.neurologylinx.com & $\begin{array}{l}\text { Web based and emailed daily news about general neurology and } \\
\text { subspecialties }\end{array}$ \\
\hline $\begin{array}{l}\text { Neurologist discussion list } \\
\text { Patients }\end{array}$ & www.neurolist.com/site & Email discussion list for neurologists \\
\hline BrainTalk communities & www.braintalk.org & Online discussion forums for patients with neurological illnesses \\
\hline $\begin{array}{l}\text { Massachusetts General Hospital } \\
\text { neurology chatrooms }\end{array}$ & www. BrainChat.org & Online discussion forums for patients with neurological illnesses \\
\hline \multicolumn{3}{|l|}{ Paediatric neurology } \\
\hline Child Neurology in the UK & www.child-neuro.org.uk & $\begin{array}{l}\text { A gateway to news, education, information and discussion about child } \\
\text { neurology }\end{array}$ \\
\hline Child Neurology & www.waisman.wisc.edu/child-neuro/ & Portal for paediatric neurology resources \\
\hline Online Mendelian Inheritance in Man & www.ncbi.nlm.nih.gov/omim/ & Catalogue of genes and genetic disorders \\
\hline \multicolumn{3}{|l|}{ Neuroradiology } \\
\hline Whole Brain Atlas & www.med.harvard.edu/AANLIB & $\begin{array}{l}\text { Superbly illustrated examples of normal brain anatomy and neurological } \\
\text { diseases }\end{array}$ \\
\hline RadiologyEducation.com & www.radiologyeducation.com & A directory of www radiology resources \\
\hline \multicolumn{3}{|l|}{ Neurophysiology } \\
\hline Clinical Neurophysiology & www.clinicalneurophysiology.org.uk & A British portal for clinical neurophysiology www resources \\
\hline TeleEMG.com & www.teleemg.com & $\begin{array}{l}\text { Useful information for clinical neurophysiologists, with an online store and } \\
\text { doctor/patient discussion groups }\end{array}$ \\
\hline $\begin{array}{l}\text { Clinical Neurophysiology on the } \\
\text { Internet }\end{array}$ & www.neurophys.com & A directory of basic and clinical neurophysiology www resources \\
\hline \multicolumn{3}{|c|}{ Professional web sites (incomplete list) } \\
\hline Association of British Neurologists & www.theabn.org & Professional association for British neurologists \\
\hline American Neurological Association & www.aneuroa.org & Professional association of North American neurologists \\
\hline American Academy of Neurology & www.aan.com & Resources for professional and practice development for neurologists \\
\hline World Federation of Neurology & www.wfneurology.org & $\begin{array}{l}\text { Promotes worldwide practice, education and research in neurology, in } \\
\text { association with the WHO }\end{array}$ \\
\hline $\begin{array}{l}\text { European Neurological Society } \\
\text { European Federation of Neurological } \\
\text { Societies }\end{array}$ & $\begin{array}{l}\text { www.ensinfo.com } \\
\text { www.efns.org }\end{array}$ & $\begin{array}{l}\text { Promotes neurology - especially education and research - in Europe } \\
\text { Promotes neurology - especially education and research - in Europe }\end{array}$ \\
\hline $\begin{array}{l}\text { British Paediatric Neurology } \\
\text { Association }\end{array}$ & www.bpna.org.uk & Professional association for British paediatric neurologists \\
\hline $\begin{array}{l}\text { International Child Neurology } \\
\text { Association }\end{array}$ & www.child-neuro.net & Professional association for paediatric neurologists worldwide \\
\hline Child Neurology Society & www.childneurologysociety.org & Professional association for North American paediatric neurologists \\
\hline British Society of Neuroradiologists & www.bsnr.co.uk & $\begin{array}{l}\text { British society to promote research and technological progress in } \\
\text { neuroradiology }\end{array}$ \\
\hline American Society for Neuroradiology & www.asnr.org & Professional society for neuroradiologists \\
\hline European Society of Neuroradiology & www.esnr.org & Professional society for neuroradiologists \\
\hline $\begin{array}{l}\text { World Federation of Interventional and } \\
\text { Therapeutic Neuroradiology }\end{array}$ & www.wfitn.org & Global organisation for interventional neuroradiologists \\
\hline $\begin{array}{l}\text { British Society for Clinical } \\
\text { Neurophysiology }\end{array}$ & www.bscn.org.uk & $\begin{array}{l}\text { Professional association to promote and assist the science and practice of } \\
\text { clinical neurophysiology }\end{array}$ \\
\hline $\begin{array}{l}\text { American Clinical Neurophysiology } \\
\text { Society }\end{array}$ & www.acns.org & Professional association for clinical neurophysiologists \\
\hline $\begin{array}{l}\text { American Academy of Clinical } \\
\text { Neurophysiology }\end{array}$ & www.pressenter.com/ dtjorneh/ & Dedicated to communication among clinical and basic neurophysiologists \\
\hline $\begin{array}{l}\text { American Association of } \\
\text { Electrodiagnostic Medicine }\end{array}$ & www.aaem.net & $\begin{array}{l}\text { Professional association for clinical neurophysiologists, affiliated to the } \\
\text { American Medical Association }\end{array}$ \\
\hline $\begin{array}{l}\text { International Federation of Clinical } \\
\text { Neurophysiology }\end{array}$ & www.ifcn.info & $\begin{array}{l}\text { Organisation to promote education and research in clinical } \\
\text { neurophysiology }\end{array}$ \\
\hline
\end{tabular}


high quality guideline repositories, not dedicated to clinical neurology, are the Scottish Intercollegiate Guidelines Network (www.sign.ac.uk) and National Guideline Clearing House (www.guidelines.gov).

\section{General neurology portals}

Without doubt the single most useful directory for neurologists is Neurosciences on the Internet. This website was established in late 1994 and it is strong on clinical neuroscience (including lists of other portals, disease related websites, patient organisations, mailing lists and discussion groups, educational resources, and useful software), although it has a slight north American bias. ${ }^{18}$ Other directories simply do not compare, so we suggest it should be the starting point for a survey of www resources in any particular area of neurology. While many websites devoted to particular categories of neurological disorder are worthy of mention (for example, www.wemove.org, dedicated to worldwide education and awareness for movement disorders), the majority are indexed by www.neuroguide.com. ${ }^{2}$

\section{Journals}

Almost every neurology journal has a website that can provide the full text of latest and recent issues. Exceptionally, only abstracts or tables of contents are available. Table 2 lists a small selection of clinical neurology journals, ranked by their impact factor; a more complete list is available from Neurosciences on the Internet and from PubMed's journal database (www. pubmed.org). Most online journals are reproductions of their print counterparts. However, some peer reviewed journals only exist in electronic format, BioMed Central Neurology being the main example (www.biomedcentral.com/bmcneurol). One of the many advantages of the electronic format is the cross referencing of bibliographies using citation linking backbones.

Sadly, the ideal of free online journals has not yet been realised in neurology, and full text access mostly requires a paid subscription. Although www.freemedicaljournals.com lists 25 such journals, the degree of access varies from complete availability to only articles published more than two years ago. Some journals offer the alternative of purchasing individual articles. Without a subscription, many offer free access to selected articles from each issue, and most provide article abstracts and email table of contents (eTOC) services. If eTOCs are not available from the journal itself, various alerting services exist to provide a comprehensive eTOC, ${ }^{4}$ while news services (below) provide edited synopses.

\section{e-Textbooks}

There are two www based general neurology textbooks. ${ }^{9}$ eMedicine Neurology is a North American multiauthored work which is freely accessible with registration, searchable, well designed, and comprehensive. MedLink Neurology is a subscription only north American electronic textbook (available on the www and a CD-ROM updated quarterly), which also includes neurosurgery topics, videos, and a discussion board, but it costs at least \$299 per year. The Neuromuscular Diseases Textbook is an unrivalled speciality resource, which provides up to date, comprehensive, intuitively indexed medical and patient information. ${ }^{10}$

Many of the resources above offer text and picture content suitable for creating lectures. Additional teaching resources include www.neuroexam.com, which illustrates the various stages of the neurological examination with streaming video. Neurologists wishing to test their knowledge on a regular basis can attempt to diagnose the Baylor College of Medicine case of the month, using the history and examination provided with an interactive battery of tests, and then return to the website the following month for the dénouement (www.bcm.tmc.edu/neurol/case.html).

\section{News and discussion}

NeurologyLinx is a website dedicated to providing news about both general and specialised neurology. Although the website is sponsored its advertisers do not influence content. News is updated daily on the website and in email bulletins, which mostly comprise information from journals and conferences.

Newsgroups offer an often unrestricted, interactive, www based means of exchanging news and (mostly) views. ${ }^{4}$ At the time of writing, the index of newsgroups-Google Groups (http://groups.google.com)—dating back to the Usenet discussion groups of 1981, did not list a dedicated neurology group, although at first glance bionet.neuroscience appeared to qualify. However, bionet.neuroscience contained around 29500 discussion threads at the time of writing, most of

\section{Table 2 Popular clinical neurology journal websites}

\begin{tabular}{|c|c|c|c|}
\hline Journal name & URL & Free full text? & $\begin{array}{l}\text { Email table of } \\
\text { contents? }\end{array}$ \\
\hline Annals of Neurology & www.interscience.wiley.com/ipages/0364-5134 & No & Yes \\
\hline Brain & http://brain.oupjournals.org & Articles $>2$ years old & Yes \\
\hline $\begin{array}{l}\text { Journal of Neuropathology and Experimental } \\
\text { Neurology }\end{array}$ & http://neur.allenpress.com/neuronline/ & No & Yes \\
\hline Stroke & http://intl-stroke.ahajournals.org & Articles $>1$ year old & Yes \\
\hline Neurology & http://intl.neurology.org & No & Yes \\
\hline Archives of Neurology & http://archneur.ama-assn.org & No & Yes \\
\hline Current Opinion in Neurology & www.co-neurology.com & No & Yes \\
\hline Cephalalgia & www.blackwellpublishing.com/journals/cha & No & Yes \\
\hline Epilepsia & www.epilepsia.com & No & Yes \\
\hline Journal of Neurology, Neurosurgery and Psychiatry & www.jnnp.com & Articles $>1$ year old & Yes \\
\hline Practical Neurology & www.blackwell-science.com/pnr & No & Yes \\
\hline
\end{tabular}


which were unscientific, unsurprisingly generating a thread devoted to the creation of a scientific neuroscience newsgroup. There are newsgroups dedicated to particular diseases (for example, sci.med.diseases.als, sci.med.diseases.alzheimer, sci.med.diseases.lyme, and sci.med.diseases.mult-sclerosis), although neurologists are unlikely to find them informative. Some patients may benefit from discussions with others in the alt.support.disorders.neurological newsgroup.

Email discussion lists provide a more secure forum for neurologists to discuss professional issues by email. One of the longest established lists of this nature is the Neurologist Discussion List, vetted by a neurologist at the medical college of Georgia; members admitted to this list can control the frequency and content of emails updating them about ongoing discussions. Neurosciences on the Internet (www.neuroguide.com/neurolist.html) has compiled the contact details of many other email discussion lists (ranging from special interests in neurology, to paediatric neurology and clinical neurophysiology).

\section{Patient information}

Portals supplying patient information of uniformly high quality about the whole breadth of neurological diseases are hard to find, but the United States' National Institute of Neurologic Disorders and Stroke (NINDS) comes close. The National Organisation for Rare Disorders (NORD) is a useful supplement to the NINDS website, especially for physicians based in the USA. MEDLINEplus (www.nlm.nih.gov/medlineplus/ neurologicdiseasesgeneral.html) provides comprehensive patient information (mostly from the NINDS website), with further links to news, diagrams, research, organisations, and medical dictionaries. In the United Kingdom, the Neurological Alliance has collated links to the major patient support organisations, one of which is the Brain and Spine Foundation that publishes a growing number of well written and freely downloadable information leaflets.

Patients' further need for communication and discussion can be fulfilled in disease specific online support groups through some of these websites. Where this is lacking, many patients - particularly those in the USA - join the www based BrainTalk communities or the Massachusetts General Hospital neurology chat rooms, to interact with nearly 55000 others about general and specific neurological conditions.

\section{PAEDIATRIC NEUROLOGY}

The best emerging resource for child neurology is Child Neurology in the United Kingdom, which despite its emphasis is an up to date source of links, news, discussion, and practice resources for paediatric neurologists worldwide. The Child Neurology website had been the leading paediatric neurology portal for some time, ${ }^{11}$ although the website's design is rudimentary and brief, but clear. Child Neurology also runs the Child-Neuro email discussion list (www. waisman.wisc.edu/archives/child-neuro.html), which can be joined by emailing mack@waisman.wisc.edu. Paediatric neurologists will also find the Neuromuscular Disease Center and Online Mendelian Inheritance in Man (OMIM) particularly valuable resources for up to date information about neuromuscular and genetic diseases respectively. ${ }^{10}$

Tables of contents and email alerts are availablesometimes requiring registration-for the main journals, Developmental Medicine and Child Neurology (www.journals. cambridge.org/

journal developmentalmedicineandchildneurology), Neuropediatrics (www.thieme.de/neuropediatrics), and Journal of Child Neurology (www.bcdecker.com/bcdecker/soc3.asp?bjid=69), but free access is not provided to the full text of the online journals.

\section{NEURORADIOLOGY}

Despite the growth of the www, there have been few dramatic developments in diagnostic and interventional neuroradiology resources. ${ }^{13}$ RadiologyEducation.com is probably the most comprehensive digital library of radiology textbooks, teaching files, journals, and CME. The collaborative hypertext of radiology, CHORUS (http://chorus.rad.mcw.edu), is a lengthy reference work of diseases and their radiological findings, albeit short on illustration, which is well complemented by the superbly illustrated Whole Brain Atlas website, also available on CD-ROM. ${ }^{14}$ The Iowa Neuroradiology Library (www.uiowa.edu/ c064s01) cannot rival the Whole Brain Atlas, but it does provide illustrations of reasonable resolution with accompanying clinical histories, suitable for use as a teaching resource. For patients, RadiologyInfo (www. radiologyinfo.org) is a source of information about radiological investigations/procedures with almost complete coverage of neuroradiology. Digital Imaging and Communications in Medicine (DICOM) has become the standard interchange format for digital imaging (http://medical.nema.org), and freeware viewers are widely available on the www. Teleradiology is outside the scope of this article, but the best source for unbiased quality filtered information about it is the Telemedicine Information Exchange (http://tie.telemed.org). Radiology news is available from Aunt Minnie (www.auntminnie.com), RadiologyLinx (www.radiologylinx.com), and the newsgroup sci.med.radiology, which has an interventional subgroup.

Tables of contents and email alerts are available from the websites of the three main diagnostic neuroradiology journals, Neuroimage (www.elsevier.com/inca/publications/store/6/2/2/9/ 2/5), American Journal of Neuroradiology (www.ajnr.org), and Neuroradiology (http://link.springer.de/link/service/journals/ 00234), but the journals' full text requires a subscription.

\section{CLINICAL NEUROPHYSIOLOGY}

There are three main portals for clinical neurophysiologists, each with their own merits. TeleEMG.com provides a wealth of resources (an online EMG manual, educational aids, a practical guide for electromyographers, the TeleEMG calculator for comparing sensory and motor conduction velocities with controls, and discussion groups), but it is a for-profit website that sells some of these products as well as the EMG assistant diagnostic program (www.emgassistant.com). Clinical Neurophysiology is a very well designed website with many up to date informative links, but some sections remain under development. Least impressive of all is Clinical Neurophysiology on the Internet, which illustrates how a website can attain a high ranking in Google by being extensively linked to, yet get away with negligible content which is, at first glance, masked by apparently comprehensive structure.

Both tables of contents and email alerts are available for the two main journals dedicated to clinical neurophysiology, Journal of Clinical Neurophysiology (www.clinicalneurophys.com) and Clinical Neurophysiology (www.elsevier.nl/inca/ publications/store/6/0/1/5/2/8/index.htt), but neither allows free access to the full text of the online journal.

\section{CONCLUSIONS}

There is no reason to be daunted by the quantity of information about neurology on the internet. Large amounts of high quality information are provided by a small selection of portals. The complete list of our recommended websites can be easily downloaded from www.jnnp.com and incorporated into your web browser as a Bookmark/Favorite file. Keeping abreast of the further progress of neurological knowledge merely requires neurologists to embrace the concept of being updated by email, and keeping an eye on JNNP Neuronline fillers and Neurology in Practice supplements. 


\section{Authors' affiliations}

R Al-Shahi, P A G Sandercock, Department of Clinical Neurosciences, Western General Hospital, Edinburgh, UK

Competing interests: None.

\section{REFERENCES}

1 Busis NA. Neurology in the electronic information age. Eur J Neurol 1999;6:385-414.

2 Busis NA, Honig LS. Neurologists and the internet. Arch Neurol 1999:56:1335-7.

3 Al-Shahi R, Kennard C. Don't slip through the net. J Neurol Neurosurg Psychiatry 2002;73:611.

4 Al-Shahi R, Sadler M, Rees G, et al. The internet. J Neurol Neurosurg Psychiatry 2002;73:619-28.
5 Thomson S, Phillips N. Internet resources for neurosurgeons and neuropathologists. J Neurol Neurosurg Psychiatry 2003;74:154-7. 6 Stone J, Sharpe M. Internet resources for psychiatry and neuropsychiatry. J Neurol Neurosurg Psychiatry 2003;74:10-12.

7 Al-Shahi R. Search engines. Pract Neurol 2001;1:60-1.

8 Al-Shahi R. Neurosciences on the internet. Pract Neurol 2002;3:182-3.

9 Zeidler M. Web based neurology "textbooks": www.medlink.com and www.emedicine.com/neuro. J Neurol Neurosurg Psychiatry (in press).

10 Nicholl D J. The Neuromuscular Disease Center: www.neuro.wustl.edu/ neuromuscular. J Neurol Neurosurg Psychiatry 2003;1:93.

11 Leber S, Mack K. The internet and clinical practice of child neurology. Curr Opin Neurol 2000;13:147-53.

12 Parton MJ. Online Mendelian inheritance in man: www.ncbi.nlm.nih.gov/omim/. J Neurol Neurosurg Psychiatry (in press) 13 Channin DS. Radiology and the internet. Acad Radiol 1995;2:721-5.

14 Summers D. Harvard Whole brain atlas: www.med.harvard.edu/ AANLIB/home.html. J Neurol Neurosurg Psychiatry 2003;74:288.

\section{NEURONLINE}

\section{Online Mendelian Inheritance in Man OMIM: www.ncbi.nlm.nih.gov/entrez}

T his website is based on a definitive work on genetic disorders, Victor McKusick's Mendelian Inheritance in Man. But whereas the book is now four years old, OMIM is updated daily—as of January 2003 it included 14120 references, gaining more than 60 a month and revising a further 500 .

The site's authors have reviewed the literature to provide a series of wellreferenced summaries of clinical and molecular features, classified on the basis of mode of inheritance. At present, the majority are defective genes or loci that have been established beyond doubt as causing a single disorder with a sole means of transmission (eg the expanded trinucleotide repeat of Huntington's disease). The remaining entries are currently of uncertain inheritance, either because the same condition can result from more than one genetic defect (such as Alzheimer's disease), or because the phenotype may overlap with another.

OMIM is best accessed through the linked Entrez system (familiar as the home of PubMed), integrating it such that a few clicks will generate literature citations, DNA sequence data, or chromosome maps. The site is best at providing an initial overview of a disease or mutation. Some conditions have generated large entries, and are helpfully linked to clinical synopses and to "Mini-MIM" - a summary of their basic details. Readers should, however, remember that OMIM is a secondary source of information-it

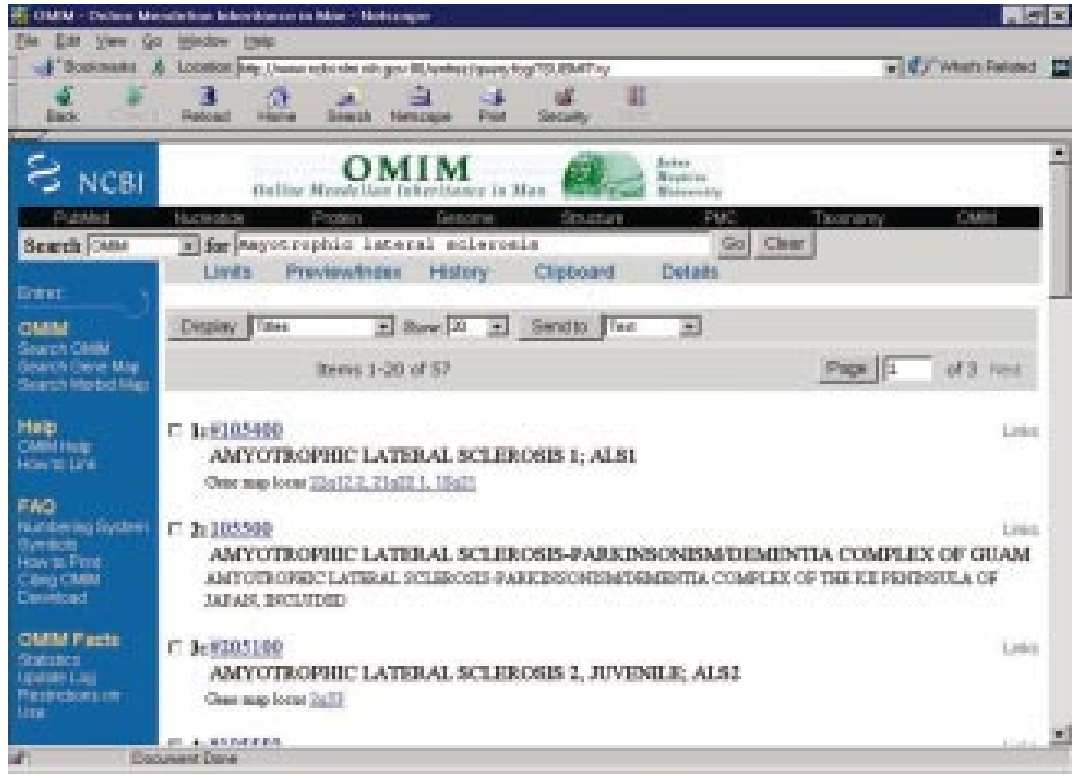

only reviews the literature and thus lags behind the very latest findings. In other instances, the limitations of the curators-geneticists but not necessarily super-specialists-become apparent, with an over emphasis on historical details and potential omission of relevant information. Searching for "spinocerebellar ataxia" generates 78 references, but omits Machado-Joseph disease (SCA3; listed only by its eponym).

Providing the caveats about the information it generates are heeded-more details and, especially, a balanced expert overview will be found by pairing an OMIM search with the reading of a recent review-OMIM is an authoritative, easy to use, and continually updated site, and an excellent first source of information for neurological clinicians and researchers.

M J Parton

Institute of Psychiatry, Box 41, De Crespigny Park, London, SE5 8AF, UK: matt.parton@dial.pipex.com 